\title{
Global and regional shock transmission: an Asian perspective
}

\author{
Nagendra Shrestha ${ }^{1 *}$ (1) and Kiyotaka Sato ${ }^{2}$ (1)
}

\author{
${ }^{*}$ Correspondence: \\ shrestha-nagendra-kj@ynu.ac.jp \\ 1 Department \\ of Economics, Yokohama \\ National University, 79-3 \\ Tokiwadai, Hodogaya-ku, \\ Yokohama 240-8501, Japan \\ Full list of author information \\ is available at the end of the \\ article
}

\begin{abstract}
This paper constructs and uses the global input-output (GIO) table with 35 industries, 29 endogenous countries and 59 exogenous countries, and develops new indices to measure the degree of shock transmission in terms of intermediate goods and valueadded embodied in production induced by negative global demand shock to finished goods. After the Global Financial Crisis (GFC) in 2008, China did not experience a large decline in economic growth, even though China's gross exports fell most severely among Asian countries. In contrast, a sharp decrease in Japanese GDP in 2009 is a consequence of a substantial decline in finished goods exports, especially in the transport equipment industry. In Japan, the shock effect tends to be absorbed in its domestic sector and is not transmitted to other foreign countries. An asymmetric pattern of shock transmission between Japan and other Asian countries can explain why Japan was more affected by GFC than other Asian countries.
\end{abstract}

Keywords: Global input-output table, Shock transmission, Asia, Production-chain, Intermediate goods trade, Value-added trade

JEL Classification: F15, F33, F42, F44

\section{Introduction}

In September 2008, the world plunged into the unprecedented global financial crisis (GFC), accompanied by a deep decline in world trade. The United States experienced the most severe downturn in trade in terms of the magnitude and speed since the late 1960s (Crowley and Luo 2011). This unprecedented collapse of world trade in 2008-2009 is referred to as the "Great Trade Collapse". According to Table 1, US imports from the selected Asian and European countries fell rapidly from the 4th quarter of 2008 through the end of 2009. US imports from Japan and Malaysia became a negative growth in the 3rd quarter of 2008, and Japan appears to have been the most severely affected by the US import decline.

Table 2 shows the GDP growth rate in 2009 and changes in exports ${ }^{1}$ to the world in selected countries from 2008 to 2009. Germany and Japan (-5.6 and $-5.5 \%$, respectively) experienced largest negative GDP growth, whereas China was affected marginally by GFC with $9.2 \%$ of GDP growth. In the meantime, Chinese gross export of

\footnotetext{
${ }^{1}$ We split gross export as sum of finished goods and intermediate goods export. See Sect. 2 and Appendix 5 for the
} details on decomposition of gross export into intermediate goods and finished goods. author(s) and the source, provide a link to the Creative Commons licence, and indicate if changes were made. The images or other third party material in this article are included in the article's Creative Commons licence, unless indicated otherwise in a credit line to the material. If material is not included in the article's Creative Commons licence and your intended use is not permitted by statutory regulation or exceeds the permitted use, you will need to obtain permission directly from the copyright holder. To view a copy of this licence, visit http:// creativecommons.org/licenses/by/4.0/. 
Table 1 US import decline from selected endogenous countries

US imports: percentage change over the corresponding period of the previous year

\begin{tabular}{|c|c|c|c|c|c|c|c|c|c|c|}
\hline & World & Japan & China & Korea & Indonesia & Malaysia & Thailand & France & Germany & UK \\
\hline $08 \mathrm{Q} 1$ & 11.2 & 3.6 & 1.7 & -2.4 & 4.5 & -3.8 & 6.2 & 10.1 & 9.0 & 9.7 \\
\hline 2008Q2 & 13.9 & 2.6 & 6.0 & 2.2 & 10.8 & 7.7 & 5.5 & 10.8 & 12.9 & 3.9 \\
\hline 2008Q3 & 14.4 & -5.1 & 10.9 & 6.8 & 13.3 & -4.0 & 8.1 & 4.0 & 1.8 & 12.1 \\
\hline 2008Q4 & -8.8 & -16.7 & 0.1 & -2.5 & 10.6 & -23.5 & -5.5 & -1.5 & -9.7 & -12.5 \\
\hline 2009Q1 & -29.7 & -41.8 & -11.5 & -17.6 & -11.2 & -36.7 & -24.0 & -21.6 & -30.3 & -23.2 \\
\hline 2009Q2 & -34.3 & -42.6 & -16.6 & -24.4 & -20.4 & -36.6 & -29.7 & -26.7 & -40.3 & -27.9 \\
\hline 2009Q3 & -29.1 & -27.5 & -18.5 & -20.5 & -26.5 & -20.1 & -20.6 & -25.8 & -27.3 & -21.4 \\
\hline 2009Q4 & -8.5 & -10.1 & -5.3 & -11.2 & -13.7 & 0.9 & -2.2 & -16.7 & -8.1 & -2.2 \\
\hline 2010Q1 & 20.7 & 26.2 & 11.9 & 2.5 & 14.9 & 21.9 & 15.7 & 10.5 & 5.3 & 10.7 \\
\hline 2010Q2 & 31.6 & 35.6 & 28.5 & 30.4 & 33.0 & 25.1 & 29.4 & 12.0 & 29.8 & 9.0 \\
\hline 010Q3 & 23.5 & 24.1 & 31.9 & 34.0 & 35.1 & 5.2 & 21.9 & 16.5 & 21.2 & 1.5 \\
\hline $010 Q 4$ & 16.3 & 18.9 & 21.2 & 31.9 & 27.1 & -1.1 & 10.8 & 13.8 & 10.1 & -0.1 \\
\hline
\end{tabular}

Bold values indicate the negative percentage change of US imports over the corresponding period of the previous year

Source: IMF, Direction of Trade Statistics, URL: https://data.imf.org/?sk=9D6028D4-F14A-464C-A2F2-59B2CD424B85

manufacturing goods declined substantially ( $\$ 207.1$ billion) due to GFC compared to Japanese gross export of $\$ 176.0$ billion. Therefore, it is quite unrealistic to explain the effect of GFC on GDP growth with respect to gross export shock. However, decline in finished goods export of Germany (\$134.1billion), Japan (\$112.1billion) and China ( $\$ 72.2$ billion) seems to be inter-related with respective GDP growths. Further, industry-breakdown of finished goods export shows Japan's finished goods export of transport equipment industry ${ }^{2}$ (mainly motor vehicles) and China's electric machinery industry ${ }^{3}$ are by far the largest in Asia. This paper attempts to answer why Japanese GDP was worst hit by GFC and China was affected only marginally, even though China plays a central role of regional processing trade in Asia, especially in the electric machinery industry (Koopman et al. 2008, 2012, and Athukorala 2009).

One useful approach is to utilize the International Input-Output (IIO) table, where bilateral trade linkages are decomposed into two types of trade, i.e., transactions of intermediate inputs and final goods ${ }^{4}$ at a detailed industry level. While it was generally hard to obtain the updated time-series data on the IIO table ${ }^{5}$ in recent years numerous attempts have been made on the construction of the time-series IIO tables. ${ }^{6}$ In

\footnotetext{
2 Transport equipment industry consists 'motor vehicles' (Y18) and 'other transport equipment's' (Y19) as listed in Appendix 3.

3 Electric industry consists 'office machinery' (Y14), 'electrical machinery' (Y15), 'Radio, Television and communication equipment' (Y16) and 'optical instruments' (Y17) as listed in Appendix 3.

${ }^{4}$ Final goods include both finished goods and capital goods.

5 A widely used internationally linked IO table in Japan is the Asian International IO (Asian IIO) table published by Institute of Developing Economies. However, the Asian IIO table is published every five years and the latest IIO table becomes available usually after more than 5-year delay. From the end of March 2014, the year 2005 Asian IIO table was published after a 9-year delay. See the website of IDE-JETRO (http://www.ide.go.jp/English/Publish/Books/Sds/material. html).

6 See, for example, Hummels, Ishii and Yi (2001), Daudin, Rifflart and Schweisguth (2011) and Johnson and Noguera (2012). See also two special issues "Global Multiregional Input-Output Frameworks" (Ed: Dietzenbacher and Tukker, 2013) of Economic Systems Research, 25(1) and "A Comparative Evaluation of Multi-Regional Input-Output Databases" (Ed: Inomata and Owen, 2014) of Economic Systems Research, 26(3) for the recent developments on internationally linked IO tables.
} 


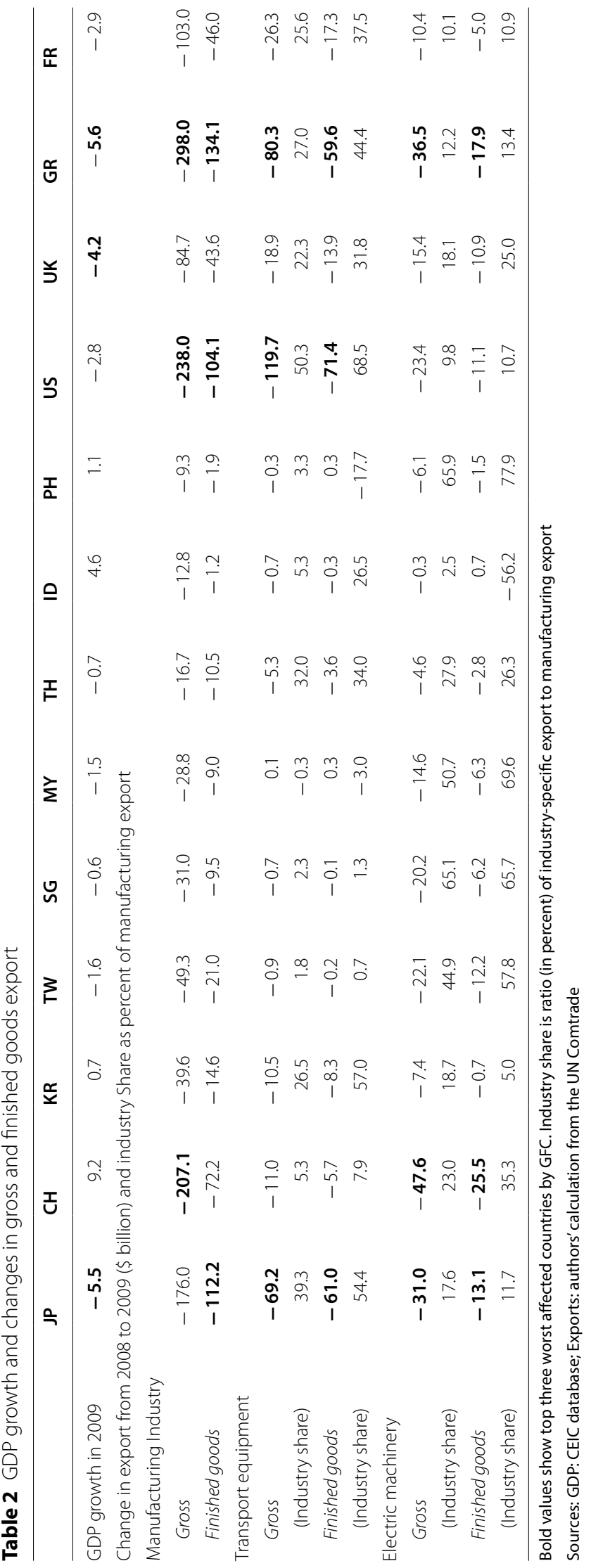


particular, dissemination of World Input-Output Database (WIOD) and Organization for Economic Cooperation and Development (OECD) Inter-Country Input-Output (ICIO) Tables are expected to contribute significantly to the research on economic linkage. ${ }^{7}$ We develop unique international input-output tables named as Global Input-Output (henceforth, YNU-GIO or GIO) tables to answer the research question of this paper. Followings are major differences between our data and other data sources. First, we attempt to capture the intermediate goods trade structure from as many countries (29 endogenous, 59 exogenous countries and Rest of the World) as possible so that we can measure the degree of shock transmission through change in demand of intermediate goods (i.e., along backward linkage direction). Unlike WIOD and ICIO, we do not treat Rest of the World as a single endogenous economy because there is higher possibility to overestimate backward and forward linkages due to endogenous treatment of Rest of the World. Further, combining countries with significantly different economic structures into one endogenous block (i.e., ROW), biases may occur in the result. Second, a major advantage of the YNU-GIO table is to include 11 Asian countries as an endogenous country and to construct annual tables from 1997 to 2012. WIOD does not include most ASEAN countries as an endogenous country, which is a major disadvantage to the study of Asian economic linkages.

To anticipate the results, we show that there is an asymmetric pattern of shock transmission between Japan and other Asian countries. Japanese finished goods exports are affected substantially by the global shock, especially in the transport equipment industry, but the shock is not transmitted globally or regionally from Japan in terms of both intermediate inputs and value-added contents. In addition, the global shock that is transmitted to Japan tends to be absorbed in Japanese domestic sectors. As a manufacturing hub, China plays a major role in supplying intermediate inputs regionally and globally, especially in the electric machinery industry, which enhances the degree of regional economic integration in Asia and also inter-regional linkages between Asia, North America and Europe. However, China's value-added transmission index to the world is comparatively higher than that of Japan, implying that Japan is more vulnerable to regional and world demand shocks than China and other countries.

The remainder of this paper is organized as follows: Section 2 presents the methods to estimate the new indices of shock transmission and the data construction of the YNUGIO tables, and Sects. 3 and 4 present the results of the shock transmission analysis and discuss the results. Finally, Sect. 5 concludes the paper.

\section{Methods: shock transmission and its measurement}

A direct impact of the GFC was a sharp decline in demand for manufacturing (both intermediate and finished) goods, especially in the United States. Exporters responded to the negative demand shock by decreasing their production and supply of production goods. Such supply-side impact has often been analyzed in the literature. Ando and Kimura (2012), for instance, analyze the GFC impact on Japanese and Asian exports

\footnotetext{
${ }^{7}$ See respective websites of the WIOD (http://www.wiod.org/index.htm) and OECD-ICIO (http://www.oecd.org/sti/ ind/input-outputtables.htm) for the details of IIO tables. For research based on the WIOD data, see, for instance, Foster and Stehrer (2013), Wang et al. (2013), Nagengast and Stehrer (2014) and Timmer et al. (2014). Moreover, details on measuring Trade in Value Added is available on http://www.oecd.org/industry/ind/measuringtradeinvalue-addedanoecd-wtojointinitiative.htm.
} 
using the most disaggregated trade data, and decompose export changes into extensive and intensive margins to examine which factor most affected Japanese and Asian exports. However, given growing regional production network in Asia, ${ }^{8}$ it is also important to investigate how the effect of global shock (i.e., decline in gross production) is transmitted to domestic and regional economies by tracing input sources (intermediate goods and value-added inputs) along the backward linkage. Such regional shock transmission can magnify the effect of negative world demand shock, driving regional economies into serious economic downturn. To get a clue to evaluate the progress of regional economic linkages and value chains, this paper investigates whether and how a sharp fall in finished goods exports of Asian countries to the world reduced domestic production and then induced subsequent decline in intra-Asian trade along the production chain (backward linkage) during the GFC. We illustrate the mechanism of shock transmission graphically and also develop new indices to measure the extent of shock transmission quantitatively in Sects. 2.1 and 2.2, respectively.

\subsection{Graphic illustration}

To evaluate the degree of global and regional economic linkages and value chains, we develop a new index of shock transmission. For a brief exposition of the new index, let us assume a four endogenous country model that consists of the United States, Japan, China and Korea (Fig. 1). Suppose that the US import demand for finished goods from China declined by $\$ 17$ billion, which is equivalent to a $10 \%$ decline in the actual amount of China's exports of finished goods to the United States in 2005 and regarded as a negative demand shock. As illustrated in Fig. 1a, China's domestic production declines by $\$ 15.9$ billion, where intermediate input contents are $\$ 10.3$ billion and value-added contents are $\$ 5.6$ billion. ${ }^{9}$ The negative US import demand shock also induces a fall in China's imports of intermediate inputs from other three countries: \$644 million from Japan, $\$ 320$ million from Korea and \$178 million from the United States.

As an illustration of the first-stage indirect effect, let us see what happens to Japanese production induced by the above direct impact. In Fig. 1b, a fall in China's imports of intermediate inputs from Japan (\$644 million) causes a decline in Japanese production, which induces a reduction in procurement of total inputs (\$613 million) from domestic sectors, where intermediate input contents are $\$ 375$ million and value-added contents are \$238 million. The decline in Japanese production also induces a fall of Japanese imports from other three countries: \$3 million from Korea, \$7 million from the United States, and \$21 million from China. This first-stage indirect effect occurs in other endogenous countries as well, that is, in Korea and the United States.

Due to the first-stage indirect effect, domestic production declines further, accompanied by a second-round reduction of not only domestic procurements but also imports of intermediate inputs from other endogenous countries. This indirect effects continue to the Nth stage where the effect becomes negligible. Finally, the magnitude of shock transmission is computed as the sum of direct and cumulative indirect effects on

\footnotetext{
${ }^{8}$ Ferrarini (2013) maps global and regional linkages in production network and vertical trade, and shows a rapid increase in the degree of regional linkage in East Asia.

9 The amounts of intermediate input contents and value-added contents presented in this section are obtained from the YNU-GIO table.
} 


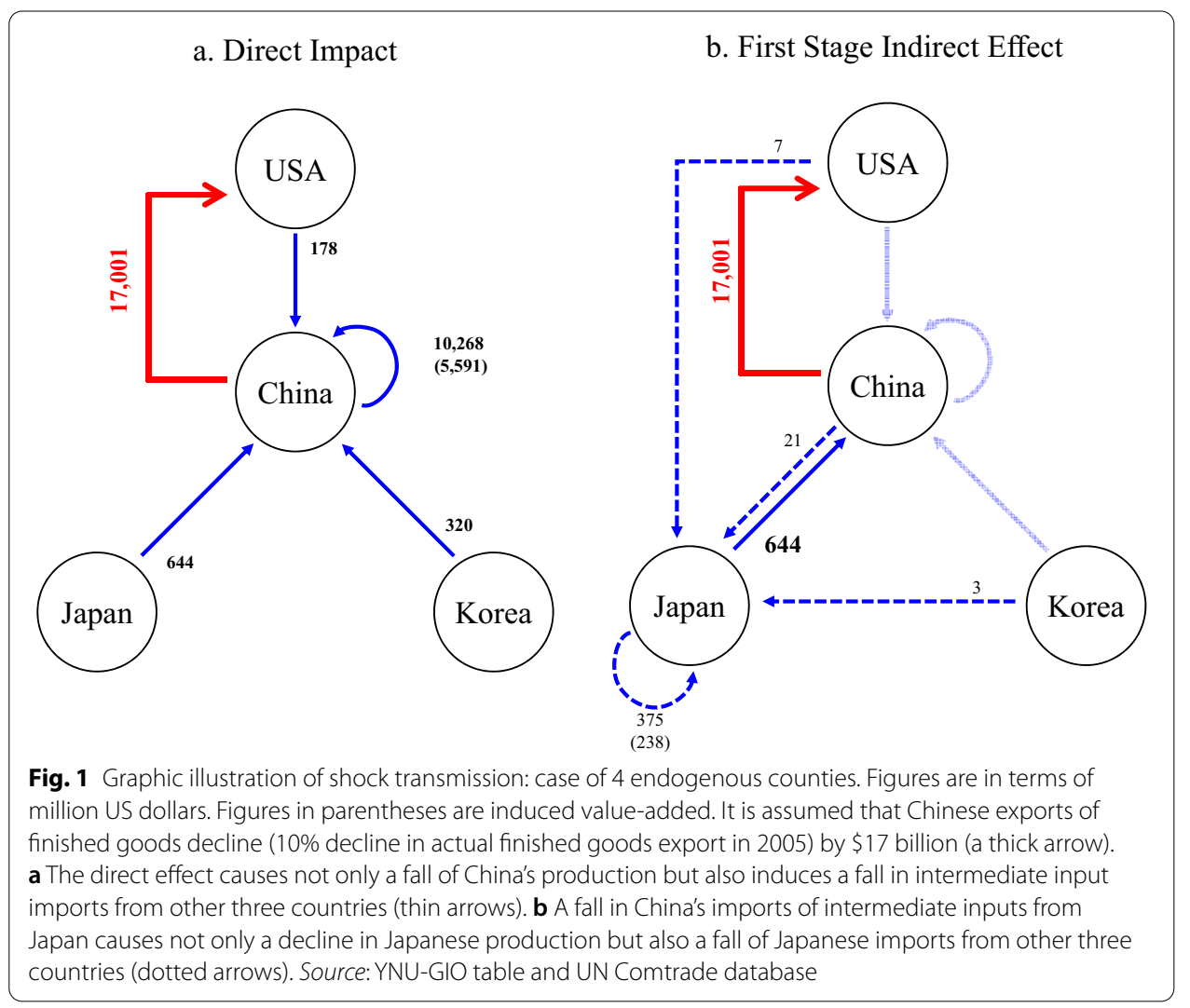

endogenous economies, as shown in Fig. 2. In this example, induced effect of decline in Chinese finished goods export to be the largest in China ( $\$ 24.7$ billion and $\$ 15.1$ billion in intermediate goods and value-added sector, respectively), a country that first experiences the export reduction of finished goods. In the meantime, Japan experience decline in intermediate goods production equivalent to $\$ 1.3$ billion plus $\$ 1.1$ billion worth of Japanese value-added. In such a way, finished goods export shock to China transmits to not only the Chinese domestic economy, but also transmits to other countries Japan, Korea and the USA through intermediate goods and value-added channels.

We have so far assumed that only one country, China, is hit by the export shock. But, it is usual that other countries are also affected by the global shock simultaneously. To assess the actual pattern and impact of shock transmission, we develop a multi-country framework to estimate total induced effect in terms of intermediate goods and valueadded, where all endogenous countries experience a decline of finished goods exports. In this paper, we estimate the amount of inducements in intermediate goods and valueadded by assuming a change in finished goods exports to the world. However, it is possible to estimate the inducements in intermediate goods and value-added due to decline in finished goods export to a particular country such as the United States (as illustrated in the example above), or to other single country, or a region such as the North America and Europe, or the world. Once, we estimate the amount of induced effects, we calculate two types of shock transmission indices: (1) shock transmitted to a country from the world and (2) shock transmitted from an individual country to the world with respect to 


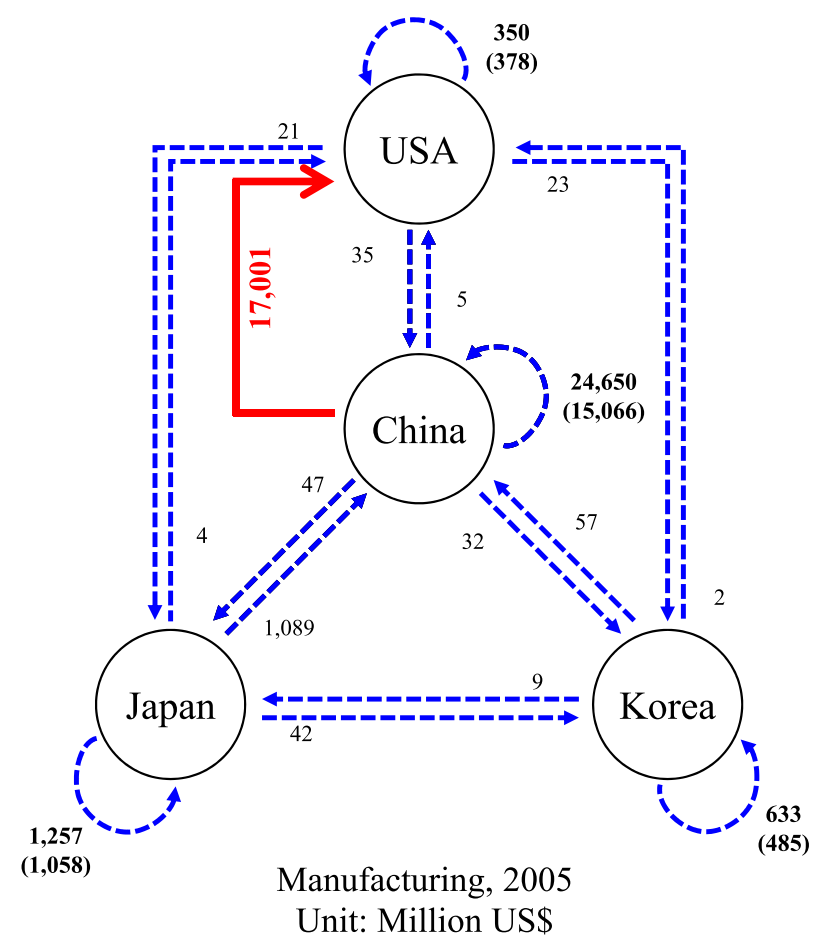

Fig. 2 Final stage direct and indirect effect and shock transmission. Figures are in terms of million US dollars. Figures in parentheses are induced value-added, which is the sum of direct and cumulative indirect effects. Source: YNU-GIO table and UN Comtrade database

intermediate goods and value-added inducements. The rest of this section shows how to derive the shock transmission indices using the three-country GIO model.

\subsection{Three-country IIO model}

To evaluate the degree of shock transmission when all endogenous countries encounter a fall of finished goods exports to the world, we first calculate the change in production inducements, where finished goods exports of country 1, 2 and 3 decline by $\Delta E_{1}^{F}, \Delta E_{2}^{F}$ and $\Delta E_{3}^{F}$, respectively. This simultaneous decline in finished goods exports induces a fall in production in three countries and can be estimated by using the global Leontief inverse matrix $\mathbf{L}$ as:

$$
\mathbf{L} \Delta \hat{\mathbf{E}}^{F}=\left[\begin{array}{lll}
L^{11} & L^{12} & L^{13} \\
L^{21} & L^{22} & L^{23} \\
L^{31} & L^{32} & L^{33}
\end{array}\right]\left[\begin{array}{ccc}
\Delta E_{1}^{F} & 0 & 0 \\
0 & \Delta E_{2}^{F} & 0 \\
0 & 0 & \Delta E_{3}^{F}
\end{array}\right]=\left[\begin{array}{ccc}
L^{11} \Delta E_{1}^{F} & L^{12} \Delta E_{2}^{F} & L^{13} \Delta E_{3}^{F} \\
L^{21} \Delta E_{1}^{F} & L^{22} \Delta E_{2}^{F} & L^{23} \Delta E_{3}^{F} \\
L^{31} \Delta E_{1}^{F} & L^{32} \Delta E_{2}^{F} & L^{33} \Delta E_{3}^{F}
\end{array}\right]
$$

The right-hand side of the above equation estimates the amount of decrease in the gross production induced by the finished goods export decline in all three countries, 


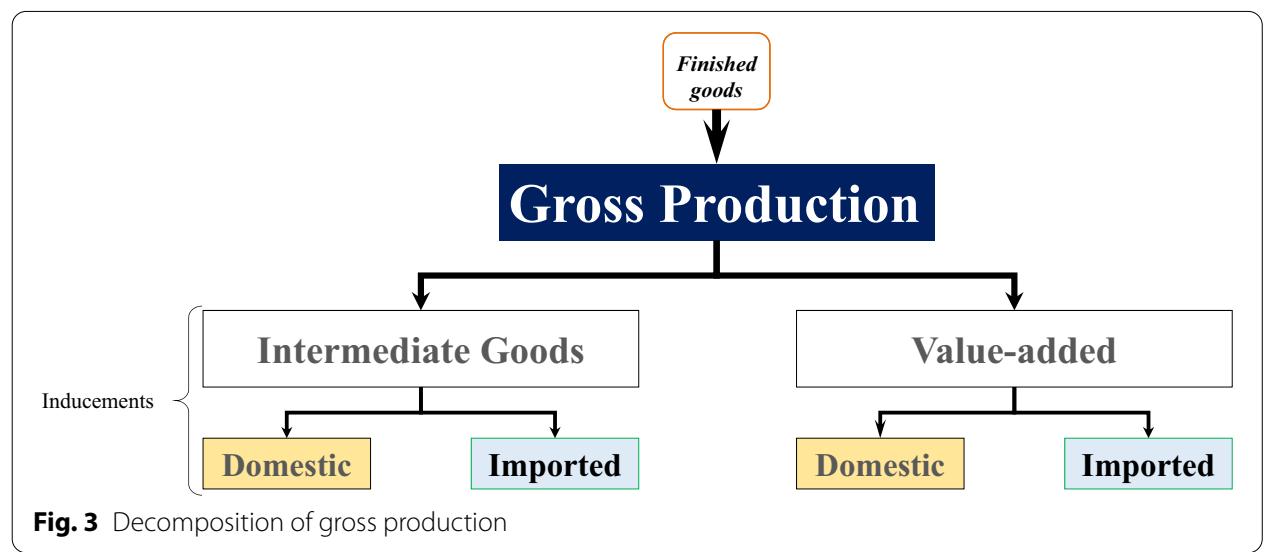

which measures the degree of shock transmission among three countries along vertical direction. ${ }^{10}$ Here, the diagonal elements are the amount of production inducements in respective countries due to the finished goods export shock, whereas off-diagonals represent induced trade between any two countries. Since gross production consists of intermediate inputs and value-added, first we separate the induced gross production in terms of intermediate goods and value-added contents so that we can analyze the effect of finished goods export shock through intermediate input channel and value-added channel using the following separation rule:

$$
\text { Inducement }(\operatorname{In} t)=\mathbf{A}\left(\mathbf{L} \Delta \hat{\mathbf{E}}^{F}\right) \text { and } \operatorname{Inducement}(V A)=\hat{\mathbf{v}}\left(\mathbf{L} \Delta \hat{\mathbf{E}}^{F}\right)
$$

where $\mathbf{A}$ is the intermediate input coefficient matrix; $\hat{\mathbf{v}}$ is the diagonal matrix of valueadded coefficients; $\mathbf{L}$ is the global Leontief inverse matrix; $\Delta \hat{\mathbf{E}}^{F}$ is a diagonal matrix of the country $i$ 's export decline of finished goods $\Delta E_{i}^{F}$. Figure 3 summarizes the decomposition of gross production induced by finished goods export in terms of inducements.

Now, for each matrices representing intermediate goods and value-added inducements, the row sums represent amount of inducements transmitted to each country from the world. In other words, the row sums indicates the direct and indirect supply of intermediate goods and value-added to the world or equivalently the inducements transmitted from the world. As the inducements transmitted from the world is a consequence of each country's finished goods export decline to the world, we define the intermediate goods and value-added shock transmission indices (denoted as $S T I_{\text {FromtheWorld }}$ ) as ratio of respective inducements transmitted from the world in each country to the total of all country's finished goods export decline. In a similar manner, the column sums represent the decline in direct and indirect demand of intermediate goods and value-added from the world to adjust the direct finished goods export shock. In this case, the intermediate goods and value-added shock transmission indices (denoted as $S T I_{\text {TotheWorld }}$ ) are defined as inducements in foreign countries (i.e., column sum minus diagonal elements

\footnotetext{
${ }^{10}$ Here, it is important to mention that, matrix $\mathbf{L} \Delta \hat{\mathbf{E}}^{F}$ includes induced trade in intermediate goods. Therefore, estimation of inducement amounts subject to gross export (as GVC approach does) tends to double count induced trade in intermediate goods.
} 
of each matrices representing the domestic inducements) relative to domestic inducements or equivalently domestic absorption to address the economic shocks experienced by a country. Here, we may use the direct finished goods export shock in a certain country in the denominator, it may not fully address the domestic components of the shock transmission. In reference to Tables 3,4 and 5 , the following rule is applied to calculate shock transmission indices:

$$
\mathrm{STI}_{\text {From the World }}=\frac{\text { Inducements transmitted from the World }}{\text { sum of direct finished goods export }},
$$

and

$$
\mathrm{STI}_{\text {To the World }}=\frac{\text { Inducements transmitted to the World }}{\text { Domestic absorption }} .
$$

We have constructed a new dataset of the internationally linked IO table, that is, the YNU-GIO table, for 16 years spanning from 1997 through $2012 .{ }^{11}$ The estimation of annual YNU-GIO tables uses (1) the National Input-Output tables (NIOTs, basically published by OECD) $)^{12}$ for years 2000, 2005 and/or nearest one; (2) annual national accounts data obtained from the United Nations Statistics Division's National Accounts Main Aggregates Database; (3) annual manufacturing industry-specific output and value-added data taken from UNIDO Industry Statistics Database (UNIDO INDSTAT); and (4) annual bilateral trade data (with intermediate goods and finished goods breakdown) downloaded from the United Nations Comtrade Database website. Appendix 4 briefly describes the datasets used for the estimation of YNU-GIO tables and Appendix 5 illustrates the estimation process of YNU-GIO table.

While a single-country IO table does not provide us with any information on source countries for imported intermediate and finished goods, the internationally linked IO table links single-country IO tables between endogenous countries using the international trade data by source/destination country and by industry. We conform the import blocks of the OECD IO table (both for imported intermediate and final goods) to the YNU-GIO classification.

We utilize trade data to estimate the industry-specific bilateral trade structures for both intermediate and finished goods trade among endogenous and exogenous countries. For this, we collect the source country breakdown trade data (from UN Comtrade Database) on imports of each endogenous country at the 4- or 5-digit SITC3 level (3,121 categories). These data are classified into three types of goods, namely intermediate, consumption and capital goods, by matching the SITC3 code with the BEC (Broad Economic Categories) code. We also conform the SITC3 categories to the ISIC3 ones to convert the trade classification into the industry classification. ${ }^{13}$ Among 3,121 SITC3 categories, 1,933 categories correspond to intermediate goods, while the remaining

\footnotetext{
${ }^{11}$ See Appendices 2 and 3 for the list of the endogenous and exogenous countries, and for that of the production industries in the YNU-GIO table.

12 For the countries OECD NIOTs are unavailable, the national tables were collected from the respective national statistics office.

13 UN web pages http://unstats.un.org/unsd/cr/registry/regsale.asp?Lg=1 and http://unstats.un.org/unsd/cr/registry/ regdnld.asp? $\mathrm{Lg}=1$ provide links for code conversion from SITC3 to ISIC3 and from SITC3 to BEC, respectively.
} 
1,188 categories are regarded as the final demand in the IO and GIO framework. ${ }^{14}$ In addition, each of the intermediate and final demand transactions is converted into the ISIC classification at the 4-digit level, which amounts to 145 categories. By aggregating the 4-digit level of ISIC3, we obtain the 2-digit level of ISIC3 (62 classifications), which is in turn converted into the OECD IO classification $\left(48\right.$ categories $^{15}$ ) and then into the 35 YNU-GIO industries. Finally, by using the import data by source country and by industry, we obtain the import share of each endogenous country for both intermediate and final goods. Thus, we can overcome a drawback of the conventional approach, such as Hummels et al. (2001) and $\mathrm{Ng}$ (2010), which uses the bilateral trade data without distinguishing intermediate goods trade from final goods trade. For the details on the estimation of YNU-GIO tables, see Appendix 5.

Utilizing the YNU-GIO table, we use new indices to measure the extent of shock transmission, whereby both direct and indirect impacts of the shock can be evaluated in multiple stages of production process. To calculate the index, we conduct a simulation analysis by generating industry-specific shocks ${ }^{16}$ to the world import demand of finished goods, which enables us to explore how and to what extent the effect of a decline in the world import demand for final goods is transmitted directly and indirectly to trade of intermediate goods and value-added through backward linkage of productions especially among Japan and Asian countries.

\section{Results: global and regional shock transmission of GFC}

In this section, we compute the extent of shock transmission of GFC in all endogenous countries with an actual change in finished goods export (all manufacturing industries, electric machinery industry and transport equipment industry) to the world during 2008-2009 using the 2009 YNU-GIO table. ${ }^{17}$ Here, we provide two indices of shock transmissions showing that (1) to what extent of the GFC shock is transmitted to individual endogenous countries from the world (transmission from the world) and (2) to what extent individual countries transmitted its shock to the regional and global partners (transmission to the world/Asia) subject to the shock in both intermediate goods and value-added.

\subsection{The effect of GFC and shock transmission in all manufacturing industries}

\subsubsection{Shock transmission in intermediate goods and value-added}

The upper panel of Table 3 shows summary of direct shock of finished goods export and its transmissions for selected endogenous countries for both intermediate goods and value-added in terms of inducements. Germany experienced largest (\$134.1 billion) decline in finished goods export followed by Japan (\$112.2 billion) and the US ( $\$ 104.1$ billion). In Asia, China ( $\$ 72.2$ billion), Taiwan ( $\$ 21.0$ billion) and

\footnotetext{
${ }^{14}$ Final demand (1,188 categories) is decomposed into consumption goods (713 categories) and capital goods (475 categories).

15 See http://www.oecd.org/dataoecd/32/56/47059256.pdf for the conversion rule from the ISIC3 to OECD IO classification.

16 We use 2009 YNU-GIO table and actual change of finished goods export to the world from 2008 to 2009 to observe the effect of GFC and report the summary of results in Tables 3-5. In addition, we also use a hypothetical economic shock of $10 \%$ decline in finished goods export to illustrate the changes in global shock transmission patterns from 1997 to 2012 in Fig. 4. Full set of results are available on request.

17 The actual amount of decline in finished goods exports of selected endogenous country from 2008 to 2009 is presented in Table 2.
} 
Korea ( $\$ 14.6$ billion) are the hardest hit countries after Japan as a consequence of GFC. However, by taking an account of direct and indirect inducement effects (see middle panel of Table 3) of respective country's final goods export shock, China's intermediate goods supply experienced the largest shock of $\$ 171.9$ billion from the world. In the meantime, Japan and Germany's intermediate goods supply declined by $\$ 164.5$ and 163.1 billion, respectively. This shows that China plays a major role, as a manufacturing hub, in supplying intermediate goods (directly and indirectly) to the world. On the other hand, Germany's value-added sector (or equivalently, GDP) experienced largest shock ( $\$ 115.7$ billion) followed by the value-added sectors of US ( $\$ 113.1$ billion), Japan ( $\$ 108.6$ billion) and China ( $\$ 74.0$ billion) due to GFC. It means that, In Asia, Japan is main value-added supplier to the world rather than China, which supplies more intermediate goods to the world.

As far as transmission of the GFC shock form individual countries to the world is concerned, Germany, Japan and China are three largest countries in magnitude. However, the extent of the direct final goods export shock experienced by each countries is different, comparison across countries does not provide a meaningful implications. Therefore, we present a new measure of GFC shock experienced by each endogenous countries (termed as shock transmission from the world) and that transmitted to foreign (and also to Asian) countries (named as shock transmission to the world and shock transmission to Asia) as shock transmission indices for both intermediate goods and value-added in lower panel of Table 3. In Asian perspective, 21.7 and $20.7 \%$ of total global shock have transmitted to China and Japan through the supply of intermediate goods to the world. Meanwhile, both countries transmit about $16.0 \%$ of its shock to foreign countries through intermediate goods demand from the world. The Chinese and Japanese rate of shock transmission to regional partners are 8.5 and 9.1\%, respectively. In other Asian countries, degree of shock transmission to the world from these countries are far more higher than that the shock transmitted to the Asian countries from the world. For instance, Korea transmits $71.0 \%$ of GFC shock to the world, whereas only $2.4 \%$ of shock is transmitted to Korea. It seems to be different from the common understanding that Korea had a tremendous negative impact on their economy from the decrease in the imports of the US. The reasons are: (1) backward linkage of Korea with the World is significantly larger than forward linkage and (2) even though the direct effect is relatively large for Korea, the net impact that remained in Korea is marginal. Singapore transmits nearly 6 times of its direct final goods export shock to the world through intermediate goods demand. In general, Asian countries illustrate higher degree of shock transmission to its regional partners compared to its transmission to the world.

Interestingly, transmission of GFC shock through value-added supply and demand (value-added transmission index) provided in Table 3 illustrates that Japanese GDP experienced 13.7\% of GFC negative shock from the world, which is by far larger than that experienced by China (9.3\%) and other Asian countries except Germany (14.6\%) and the US (14.3\%). In contrast, Japan's shock transmission through value-added (8.9\%) is much smaller than that for three major European economies (19.2\% for Germany, and 14.3\% each for UK and France) and China (13.9\%). Moreover, value-added transmission indices to the world for other Asian countries are also relatively higher (ranging 


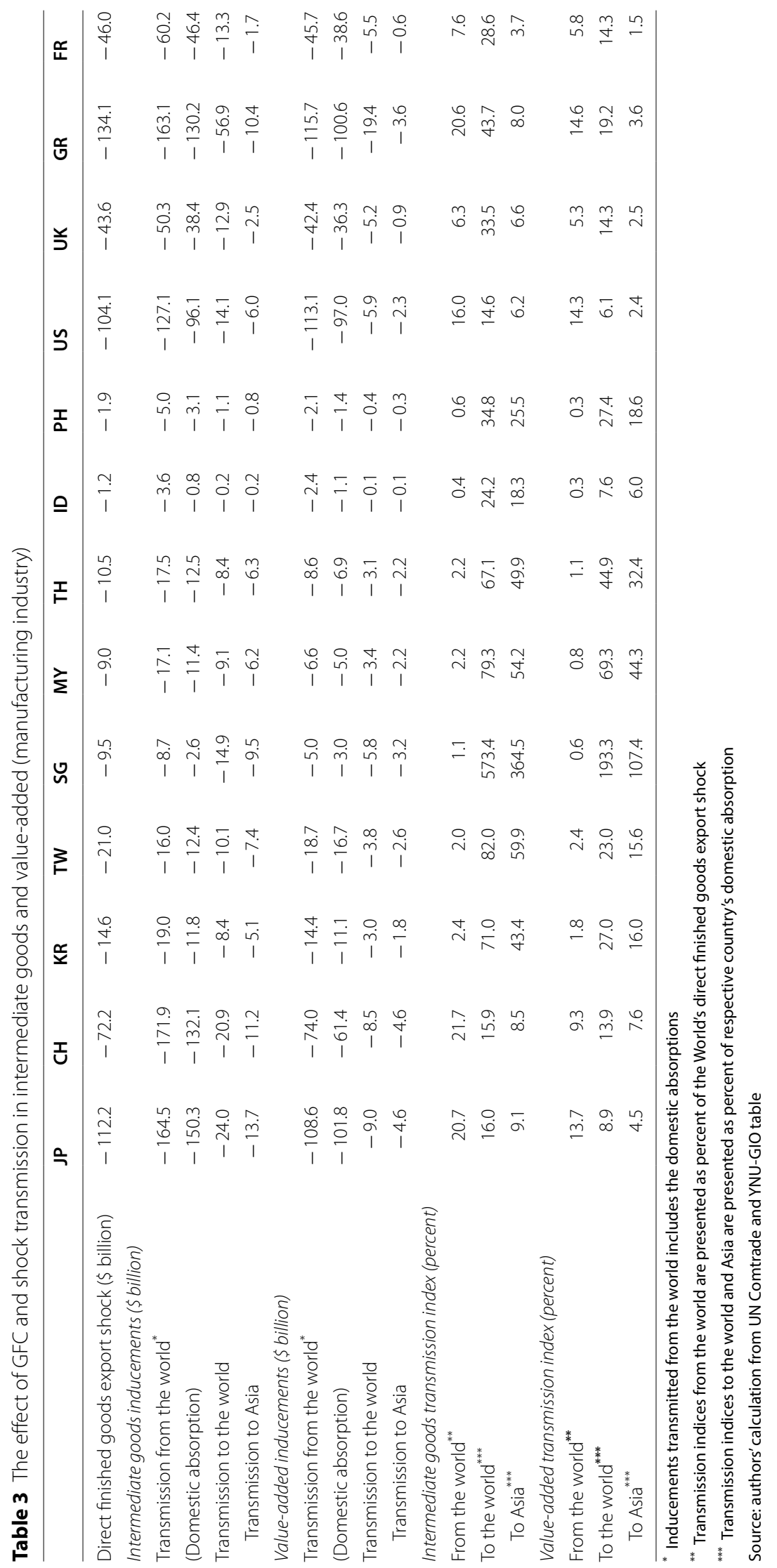


from 23.0\% for Taiwan to 193.3\% for Singapore) than Japan with an exception of 7.6\% for Indonesia. Such situation implies that Japan is a major supplier of value-added (among Asian countries) to the world, but demands less value-added from the world compared to Germany, China and other regional partners. Or equivalently, Japanese GDP experienced substantial suffering from inbound value-added shocks due to GFC, while the shock is not transmitted (i.e., the shock is absorbed in domestic economy) to foreign and regional countries from Japan as compared to other regional countries. This is the main reason why Japanese GDP in 2009 marked lowest (-5.5\%) growth in Asia.

Moreover, the extent of the GFC shock transmitted to Asian countries from the world and that transmitted to the world or regional partners from Asian countries illustrates asymmetric patterns of shock transmission. For example, value-added shock transmission indices from the world are relatively smaller except for Japan and China, whereas shock transmission to the foreign and regional economies are higher except for Japan, China and Indonesia.

\subsection{Shock transmission in electric machinery and transport equipment industries}

Tables 4 and 5 show industry-specific (electric machinery and transport equipment industries) ${ }^{18}$ summary of direct effect of GFC and shock transmission in intermediate goods and value-added. Table 4 clearly indicates that Chinese electric machinery industry is worst hit by GFC compared to any other countries in terms of direct shock ( $\$ 25.5$ billion presented in Table 2 ), indirectly induced intermediate goods ( $\$ 64.0$ billion, presented in Table 4) and indirectly induced value-added ( $\$ 24.5$ billion, presented in Table 4). However, in Chinese electric machinery industry, it is important to notice, from Table 4, that, (1) $16.9 \%$ of value-added shock transmission is by far lower than $44.2 \%$ of intermediate goods shock transmission; (2) the extent of shock transmission from China to the world (6.4 and 5.7\%, respectively, for shock transmission through intermediate goods and value-added) is relatively larger than Japanese (1.5 and $0.9 \%$ for shock transmission through intermediate goods and valueadded, respectively) and (3) the share of electric machinery industry due to the GFC shock, the worst hit industry in China, is only $35.3 \%(=(-25.5) /(-72.2)$, see Table 2$)$ of direct finished goods export shock. As a consequence, impact of GFC on Chinese value-added sector is marginal compared to that on intermediate goods production in China.

Table 5 presents the effect of GFC in transport equipment industry. In contrast to electric machinery industry, the share of GFC shock is $54.4 \%$ in Japanese transport equipment industry (see Table 2), and the intermediate goods and value-added transmission indices from the world is 31.9 and $18.1 \%$, respectively, compared to mere $7.9 \%$ industry share, and 8.1 and $3.0 \%$ of intermediate goods and value-added transmission rates, respectively, in Chinese transport equipment industry. In Korean case, the weight of transport equipment industry is $57.0 \%$ (see Table 2), however, the magnitude of shock transmitted to Korea from the world is relatively low and that transmitted to the world from Korea is high. Such evidence indicates that GFC predominantly affected the Japanese economy due to largest decline of finished transport equipment goods export

${ }_{18}$ We select two industries (electric machinery and transport equipment) to discuss the results, because these two are major industries to promote production networks and economic integration in Asia. 


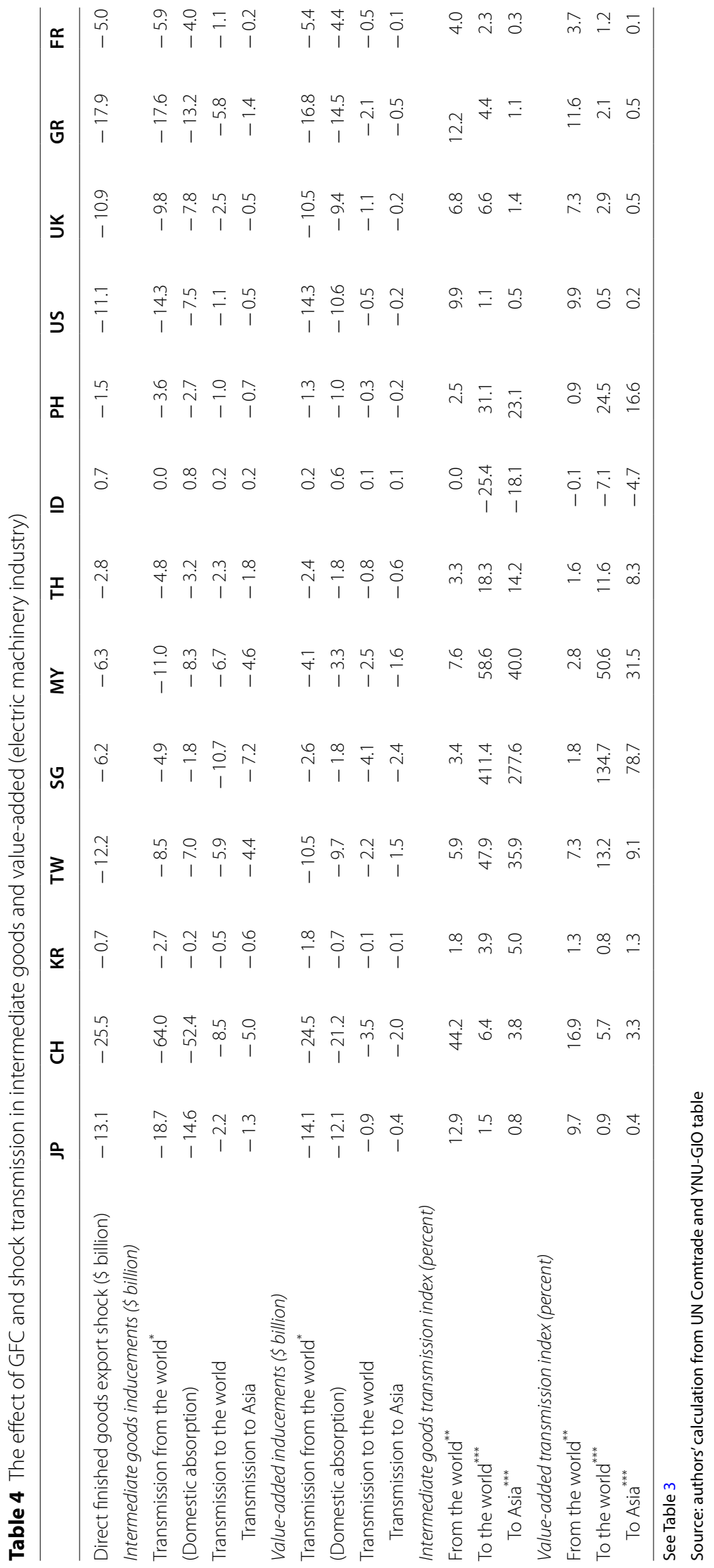




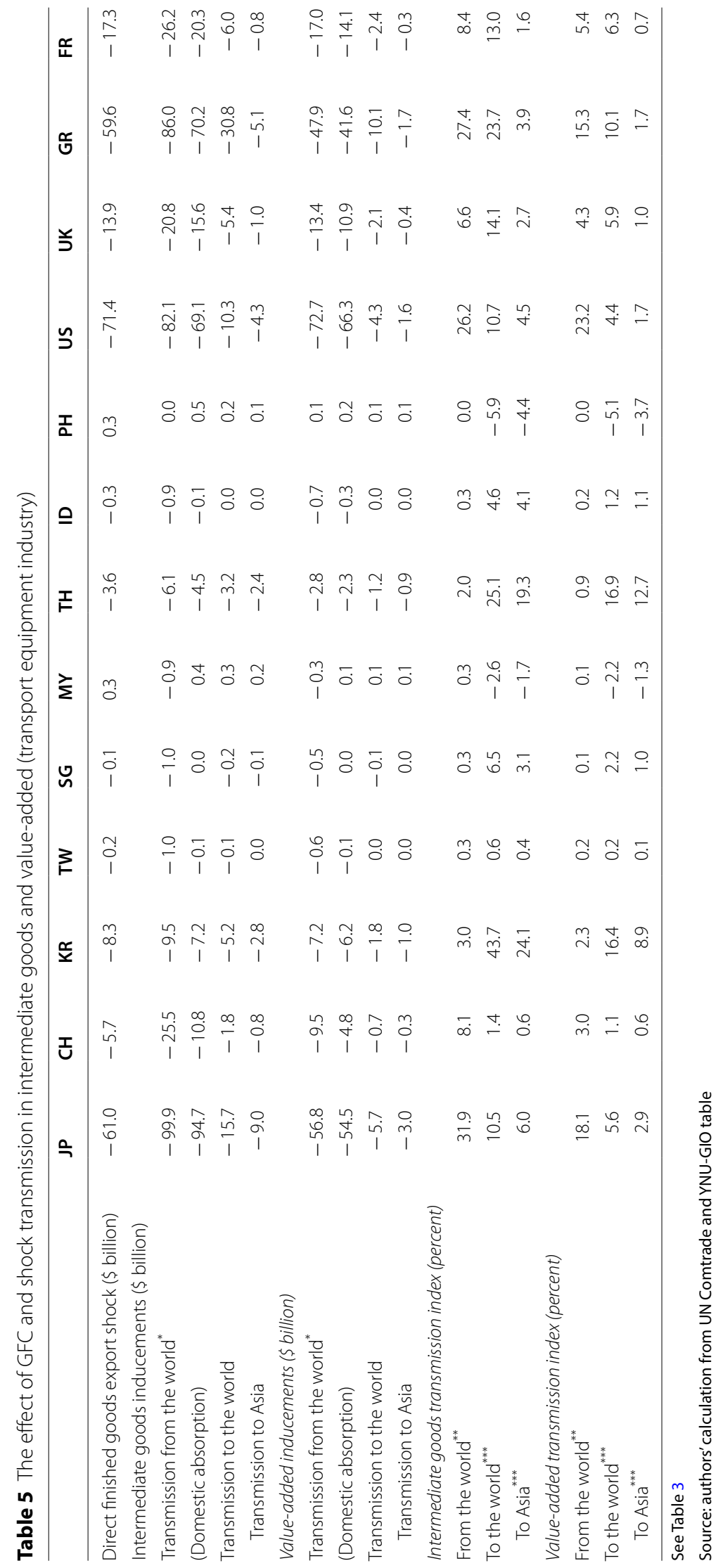


compared to the other Asian countries. Moreover, Tables 4 and 5 evidently illustrate asymmetric shock transmission patterns not only across the two selected industries, but across countries in Asia also.

\section{Discussions: changes in regional linkages}

We have so far analyzed the effect of GFC on shock transmission focusing on the Asian region using 2008-2009 data. It is also worth investigating how regional and global linkages for intermediate inputs and value-added contents changed. We first, calculate and summarize transmission of hypothetical shock using $10 \%$ decline of finished goods export to the world in each year from 1997 to 2012 and corresponding year's YNU-GIO table in terms of regional procurements of intermediate goods and value-added from Asia, North America and Europe. Figure 4 shows not only the intra- and inter-regional linkage of procurements of intermediate inputs and value-added contents, but it also shows the world's dependence on each region. In the far left figure, Asian countries exhibit a remarkable growth in regional procurements of intermediate inputs and value-added from 1997 to 2006, however the Asian intra-regional dependence significantly declined until 2009 and started to gain some momentum later. On the other hand, Asia's procurements from North America and Europe do not show an increase during 1997-2012 period in general. In particular, growing trend in regional procurement of value-added demonstrated by Asia supports the recent findings that regional economic integration in Asia has been mainly driven by growing regional production network and fragmentation. ${ }^{19}$

Three figures on the left in Fig. 4 indicate that the level of regional procurements of intermediate inputs and value-added is higher in Europe than in Asia and North America. An increasing trend in European intra-regional dependence, subject to both

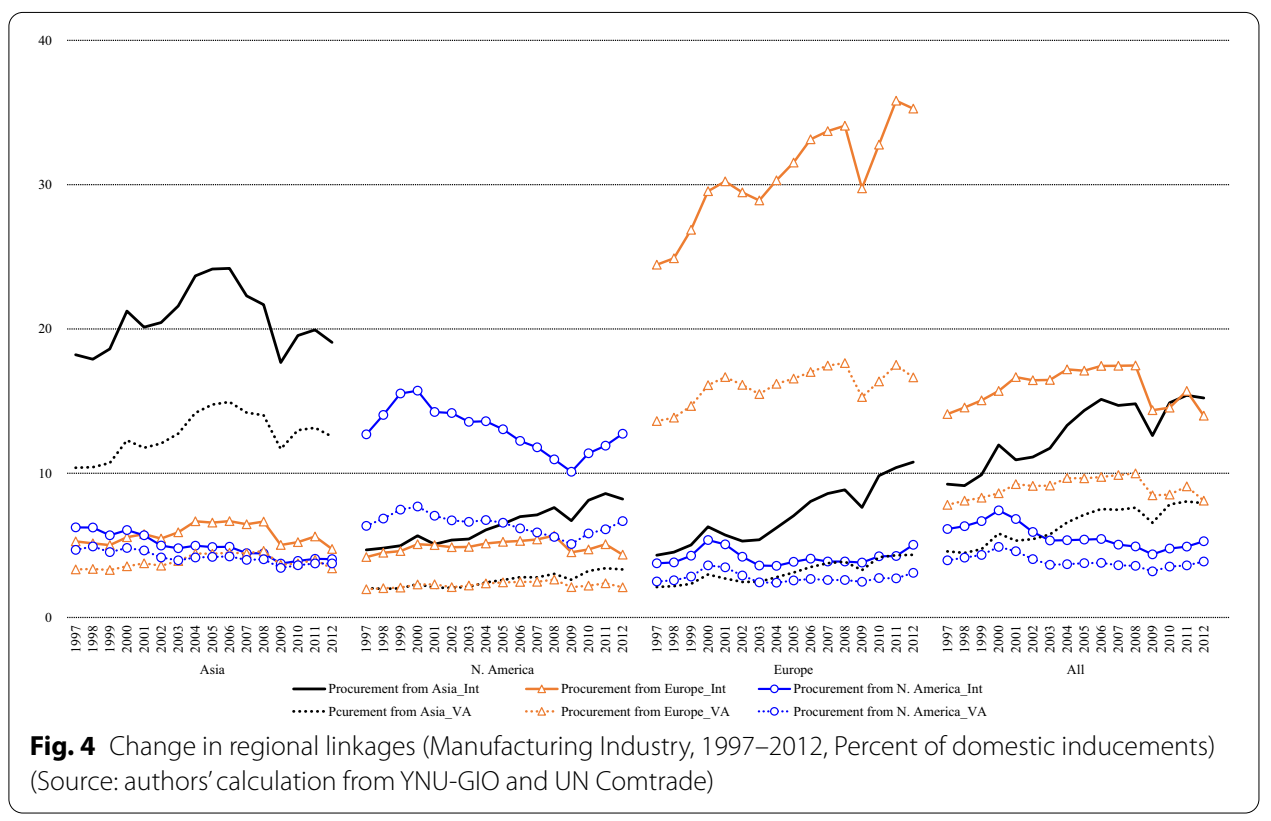

${ }^{19}$ Kimura and Obashi (2011) make a good review on the recent research on regional production network in Asia. 
procurements, can be observed during the sample period, whereas North American intra-regional dependence continuously declined from 2000 until 2009 and then it started to increase again. In value-added terms, North America does not show a significant change. Interestingly, both European and North American countries have increased their procurements of intermediate inputs, in particular, and procurements of valueadded, to some extent, from Asian countries. Notice the higher extent of Asian procurements of intermediate goods and value-added than that of European procurements in North America, which implies that Asia is major intermediate goods and value-added supplier to North America compared to Europe.

The far right figure in Fig. 4 illustrates the procurement ratio of intermediate goods and value-added from Asia, Europe and North America. In 2012, Asian procurements of intermediate goods overtook European procurements to the world. In value-added terms, Europe is still the major supplier to the world, however, the gap between Asia and Europe has reduced significantly. The above observation suggests that Asia shows the significant progress of regional economic linkages and also becomes more integrated into global production network through intermediate input and value-added trade.

\section{Concluding remarks}

We developed a new index to measure the extent of shock transmission due to global demand shock in finished goods export. The finished goods demand shock transmits to respective country's domestic production, which in turn transmits to its domestic economy and foreign partner economies via induced intermediate goods and value-added. We standardize the foreign inducements relative to domestic inducements to make an international comparison. Our methodology differs from the GVC (Global Value Chain) approach as the GVC model treats intermediate goods trade as both endogenous and exogenous variables simultaneously. Moreover, we use an entirely new set of 16 annual globally linked IO tables, called as YNU-GIO tables, from 1997 to 2012 to reveal the extent of shock transmission due to exogenous shock in finished goods trade. The new data set focuses primarily on dynamic structural changes and economic integration in Asian region that are not covered fully by existing data sets.

We have shown that there is an asymmetric pattern of shock transmission between Japan, China, Korea and other Asian countries. Japan is affected substantially by the direct global shock (specifically in transport equipment industry) and the induced shock is not transmitted to foreign countries from Japan as compared to the shock transmitted to foreign countries from other Asian and non-regional countries in terms of both intermediate inputs and value-added contents. The global shock tends to be absorbed in the Japanese domestic sectors. As a manufacturing hub, China plays a major role in supplying intermediate inputs regionally and globally, especially in the electric machinery industry. However, China's rate of shock transmission to foreign countries is higher than the Japanese one (in particular, value-added inducements in foreign countries), which means that the Chinese GDP sector experiences only a marginal negative shock. Even though China enhances regional economic 
integration through intermediate input transactions, Japan is more vulnerable to regional or global demand shock.

Our research can be extended in the following ways. Processing trade accounts for a large share in China's total trade, but it is not taken into account in this paper. Recently, Koopman et al. $(2008,2012,2014)$ attempt to analyze the effect of processing trade on global value chains. This line of research is necessary to evaluate the role of China as a manufacturing hub more rigorously. Further, this paper aims to assess the shock transmission mechanism due to international trade only, we have not addressed internal transaction of finished goods. Finally, Asian economic integration may have changed before and after 2012 as rapid appreciation of the yen from 2009 to $2012^{20}$ and dramatic depreciation of the yen afterwards. Further efforts to update the YNU-GIO table will be necessary.

\section{Appendix 1. GVC model under the Three-Country IIO Model}

Let us assume a three-country GIO table presented in Figure 5, where each country produces in a single tradable sector. Each country produces a good that can be consumed as a final good or used as an intermediate input. ${ }^{21}$ Here, for three countries $\mathbf{i}$ and $\mathbf{j}, \mathbf{Z}=\left(\mathbf{Z}^{i j}\right)$ and $\mathbf{F}=\left(\mathrm{F}^{i j}\right)$ are matrices of intermediate goods and final goods transactions, respectively; $\mathbf{Y}=\left(\mathrm{Y}^{i}\right)=\left(\mathrm{Y}^{j}\right)^{\prime}$ is a vector of gross output and $\mathbf{V}=\left(\mathrm{V}^{j}\right)^{\prime}$ is vector of valueadded inputs. Then we can easily derive the input-output equation, for the GIO table given in Figure 5, in matrix form as:

$$
\mathbf{Y}=(\mathbf{I}-\mathbf{A})^{-1} \mathbf{F u}=\mathbf{L F} \mathbf{u},
$$

where $\mathbf{A}$ is $3 \times 3$ global intermediate input coefficient matrix, $\mathbf{L}$ is the global Leontief inverse matrix of size $3 \times 3$, $\mathrm{F}$ is a matrix of size $3 \times 3$ and $\mathbf{u}$ is a $3 \times 1$ vector of ones.

Now, let us rearrange transactions of intermediate and final goods as vectors of domestic use and export, such that $\mathbf{Z}^{D}=\left[\begin{array}{l}\mathrm{Z}_{1}^{D} \\ \mathrm{Z}_{2}^{D} \\ \mathrm{Z}_{3}^{D}\end{array}\right]=\left[\begin{array}{l}\mathrm{Z}^{11} \\ \mathrm{Z}^{22} \\ \mathrm{Z}^{33}\end{array}\right] \mathbf{F}^{D}=\left[\begin{array}{l}\mathrm{F}_{1}^{D} \\ \mathrm{~F}_{2}^{D} \\ \mathrm{~F}_{3}^{D}\end{array}\right]=\left[\begin{array}{l}\mathrm{F}^{11} \\ \mathrm{~F}^{22} \\ \mathrm{~F}^{33}\end{array}\right]$ $\mathbf{E}^{Z}=\left[\begin{array}{l}\mathrm{E}_{1}^{Z} \\ \mathrm{E}_{2}^{Z} \\ \mathrm{E}_{3}^{Z}\end{array}\right]=\left[\begin{array}{l}\mathrm{Z}^{12}+\mathrm{Z}^{13} \\ \mathrm{Z}^{21}+\mathrm{Z}^{23} \\ \mathrm{Z}^{31}+\mathrm{Z}^{32}\end{array}\right] \mathbf{E}^{F}=\left[\begin{array}{c}\mathrm{E}_{1}^{F} \\ \mathrm{E}_{2}^{F} \\ \mathrm{E}_{3}^{F}\end{array}\right]=\left[\begin{array}{l}\mathrm{F}^{12}+\mathrm{F}^{13} \\ \mathrm{~F}^{21}+\mathrm{F}^{23} \\ \mathrm{~F}^{31}+\mathrm{F}^{32}\end{array}\right]$, where $\mathbf{Z}^{D}$ and $\mathbf{E}^{Z}$ are intermediate goods supplied to domestic market and foreign countries, respectively; $\mathbf{F}^{D}$ is domestically consumed final goods; and $\mathbf{E}^{F}$ is the exported finished goods. It follows that,

$$
\mathbf{Z u}=\mathbf{Z}^{D}+\mathbf{E}^{Z}
$$

and

$$
\mathbf{F u}=\mathbf{F}^{D}+\mathbf{E}^{F} .
$$

Substituting Eq. (3) in Eq. (1), we get,

$$
\mathbf{Y}=\mathbf{L}\left(\mathbf{F}^{D}+\mathbf{E}^{F}\right)=\mathbf{L} \mathbf{F}^{D}+\mathbf{L} \mathbf{E}^{F}
$$

\footnotetext{
${ }^{20}$ See, for instance, Shimizu and Sato (2015).

${ }^{21}$ We assume that each country has only one production sector. This assumption can be easily extended to a multiproduction sector model with the same matrix and vector notations.
} 


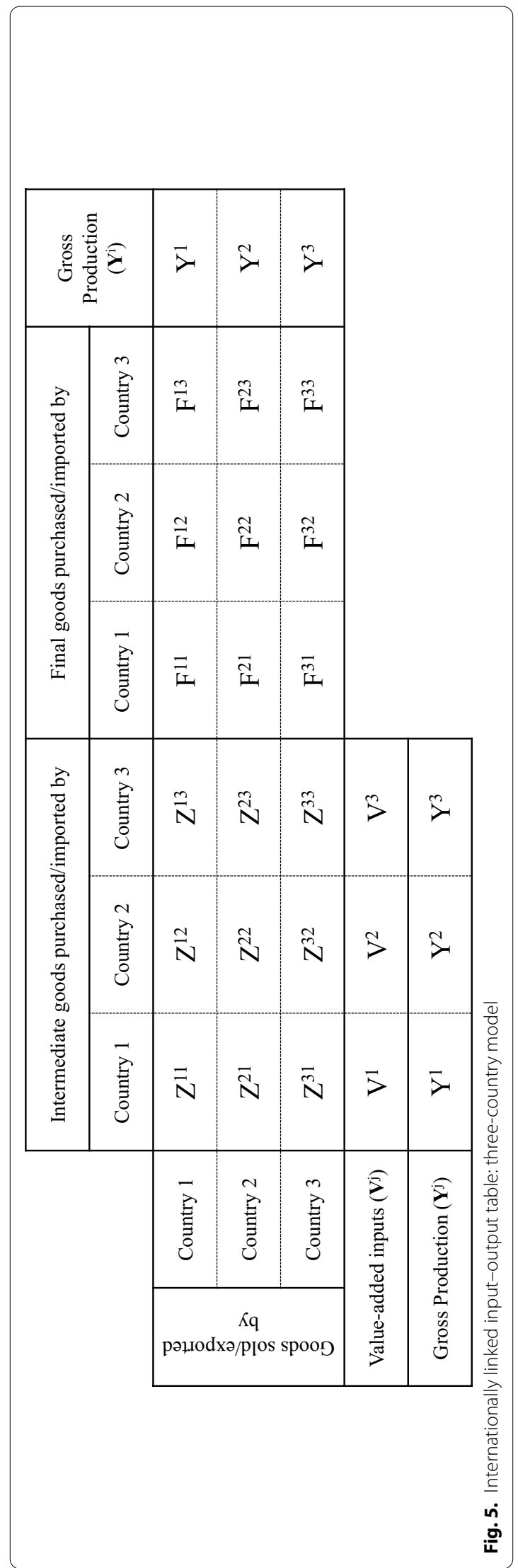


Equation (4) implies that the gross output vector $(Y)$ is sum of productions induced by domestic consumption $\left(\mathrm{F}^{\mathrm{D}}\right)$ and export $\left(\mathrm{E}^{\mathrm{F}}\right)$ vectors of finished goods. Thus the valueadded associated with induced production can be written as

$$
\mathbf{V}=\hat{\mathbf{v}}\left(\mathbf{L} \mathbf{F}^{D}+\mathbf{L} \mathbf{E}^{F}\right)
$$

where $\hat{\mathbf{v}}$ is diagonal matrix of value-added coefficients.

The global value chain (GVC) in existing literatures estimates the induced value-added generated by gross export (say, $\mathbf{E}^{G}=\mathbf{E}^{Z}+\mathbf{E}^{F}$ ) using the GIO data as follows:

$$
\mathbf{G V C}=\hat{\mathbf{v}} \mathbf{L E} \mathbf{E}^{G}=\hat{\mathbf{v}}\left(\mathbf{L} \mathbf{E}^{Z}+\mathbf{L} \mathbf{E}^{F}\right) .
$$

Here, Eq. (6) represents the value-added associated with the production induced by export of intermediate goods $\left(\mathbf{L E}^{Z}\right)$ and that induced by export of final goods $\left(\mathbf{L E}^{F}\right)$. Now, the gross production under GVC assumption (say, $\mathbf{Y}_{G V C}$ ) can be written as sum of productions induced by domestic final demand vector $\mathrm{F}^{\mathrm{D}}$, export vector of final goods $\mathrm{E}^{\mathrm{F}}$ and export vector of intermediate goods $\mathrm{E}^{\mathrm{Z}}$, and using Eq. (4) we get:

$$
\mathbf{Y}_{G V C}=\mathbf{L} \mathbf{F}^{D}+\mathbf{L E}^{F}+\mathbf{L E}^{Z}=\mathbf{Y}+\mathbf{L E}^{Z} .
$$

Note that, for the given global Leontief inverse matrix $L$ and non-zero $E^{\mathrm{Z}}, \mathbf{Y}_{G V C}$ exceeds the gross output $\mathbf{Y}$ provided in the GIO table, which is an impossible phenomenon. In GIO framework, global transaction of intermediate goods are treated as endogenous variable and are induced by production of final goods only. It means that, inclusion of production induced by intermediate goods estimated by using the global Leontief inverse matrix will evidently overestimate the actual gross production and hence overestimates the actual value-added amounts. However, if a national Leontief inverse (computed from single-country IO table) is substituted for the global Leontief inverse, then Eq. (7) holds true. Because, in single-country $\mathrm{IO}$ model, both $\mathrm{E}^{\mathrm{F}}$ and $\mathrm{E}^{\mathrm{Z}}$ are exogenous variable.

\section{Appendix 2. Endogenous and exogenous countries of the YNU-GIO table}

(a) Endogenous country list:

\begin{tabular}{llll}
\hline Asia (11) & North America (3) & Europe(12) & Others (3) \\
\hline Japan (JP) & USA (US) & France (FR) & Australia (AU) \\
China (CH) & Canada (CA) & Germany (GR) & Brazil (BR) \\
Korea (KR) & Mexico (MX) & Austria (AT) & South Africa (SA) \\
Taiwan (TW) & & Belgium (BG) & \\
Singapore (SG) & Finland (FN) & \\
Malaysia (MY) & Ireland (IR) & \\
Thailand (TH) & Italy (IT) & \\
Indonesia (ID) & Luxembourg (LX) & \\
Philippines (PH) & Netherlands (NL) \\
Vietnam (VT) & & Portugal (PT) \\
India (IN) & & Spain (SP) & \\
& & UK (UK) & \\
\hline
\end{tabular}

(b) Exogenous country list: 


\begin{tabular}{|c|c|}
\hline $\begin{array}{l}\text { Country/ } \\
\text { group }\end{array}$ & List of countries \\
\hline HK (1) & Hong Kong \\
\hline $\mathrm{ROA}(30)$ & $\begin{array}{l}\text { Afghanistan, Bangladesh, Bhutan, Maldives, Nepal, Pakistan, Sri Lanka, Armenia, Azerbaijan, Bahrain, Brunei } \\
\text { Darussalam, Cambodia, Macau, North Korea, Georgia, Israel, Jordan, Kazakhstan, Kyrgyzstan, Lao PDR, } \\
\text { Lebanon, Mongolia, Myanmar, Oman, Syria, Tajikistan, Turkey, Turkmenistan, Uzbekistan and Yemen }\end{array}$ \\
\hline ROE (16) & $\begin{array}{l}\text { Russia, Bulgaria, Cyprus, Czech Rep., Denmark, Estonia, Greece, Hungary, Latvia, Lithuania, Malta, } \\
\text { Poland, Romania, Slovakia, Slovenia and Sweden }\end{array}$ \\
\hline OPEC (12) & Algeria, Angola, Ecuador, Iran, Iraq, Kuwait, Libya, Nigeria, Qatar, Saudi Arabia, UAE and Venezuela \\
\hline ROW & Rest of the World \\
\hline
\end{tabular}

Numbers in parenthesis represent number of countries treated endogenously in the YNU-GIO Database. ROA, ROE and OPEC represent Rest of Asia, Rest of Europe and oil producing countries, respectively.

\section{Appendix 3: List of production industries of the YNU-GIO table}

\begin{tabular}{|c|c|}
\hline Industry Code & Name of Industry \\
\hline Y01 & Agriculture, hunting, forestry and fishing \\
\hline Y02 & Mining and quarrying \\
\hline Y03 & Food products, beverages and tobacco \\
\hline Y04 & Textiles, textile products, leather and footwear \\
\hline Y05 & Wood and products of wood and cork \\
\hline Y06 & Pulp, paper, paper products, printing and publishing \\
\hline Y07 & Coke, refined petroleum products and nuclear fuel \\
\hline Y08 & Chemicals and pharmaceuticals \\
\hline Y09 & Rubber and plastics products \\
\hline Y10 & Other non-metallic mineral products \\
\hline Y11 & Basic metals \\
\hline Y12 & Fabricated metal products, except machinery and equipment \\
\hline Y13 & Machinery and equipment \\
\hline Y14 & Office, accounting and computing machinery \\
\hline Y15 & Electrical machinery and apparatus \\
\hline Y16 & Radio, television and communication equipment \\
\hline Y17 & Medical, precision and optical instruments \\
\hline Y18 & Motor vehicles, trailers and semi-trailers \\
\hline Y19 & Other transport equipment \\
\hline Y20 & Other manufacturing; recycling (include furniture) \\
\hline Y21 & Electricity, gas and water supply \\
\hline Y22 & Construction \\
\hline Y23 & Wholesale and retail trade; repairs \\
\hline Y24 & Hotels and restaurants \\
\hline Y25 & Transport \\
\hline Y26 & Post and telecommunications \\
\hline Y27 & Finance and insurance \\
\hline Y28 & Real estate activities \\
\hline Y29 & Renting of machinery and equipment \\
\hline Y30 & Computer and related activities \\
\hline Y31 & Research and development \\
\hline Y32 & Other business activities \\
\hline Y33 & Public administration and defense; compulsory social security \\
\hline Y34 & Education \\
\hline Y35 & Health, social work and other services \\
\hline
\end{tabular}




\section{Appendix 4: Descriptions of Data used for Estimation of the YNU-GIO Tables}

We basically use single-country input-output tables (or equivalently, national inputoutput tables, NIOT) published by OECD for years 2000, 2005 and/or nearest one. As many Asian economies are not covered in OECD input-output database, we further collect national IOTs of Malaysia (2000 and 2005 from Department of Statistics, Malaysia), the Philippines (2006 from National Statistical Coordination Board, the Philippines), Singapore (2005 and 2007 from Singapore Department of Statistics, Singapore), Thailand (2000 from Office of the National Economic and Social Development Board, Thailand) and Vietnam (2007 from General Statistics Office of Vietnam) and reorganize all the tables in common 35 industrial classification compatible with the OECD tables in millions of respective national currency at current price.

We use annual national accounts data at current prices in national currency (GDP, 7 industry breakdown value-added, export and import of goods and services) and annual exchange rate data vis-à-vis US dollars obtained from the United Nations Statistics Division's National Accounts Main Aggregates Database. Sources for Taiwanese national account data and exchange rates data are National Statistics, Republic of China (Taiwan) and CEIC database, respectively.

Detailed manufacturing industry (two-digit ISIC3 classification) data on output and value-added in million current national currency are taken from the UNIDO Industry Statistics Database (UNIDO INDSTAT). Industrial classification of UNIDO data are rearranged as per 35 classifications in YNU-GIO's manufacturing industries.

Annual trade data are download (4- or 5- digit SITC3 classification, in current US Dollar) from the UN Comtrade database website. We convert SITC3 data into YNU-GIO classification according to its use for production (used as intermediate goods) or for final consumption (i.e., final goods) based on the Broad Economic Categories (BEC). We do not use the trade data directly while compiling the YNU-GIOs, but calculate source and destination breakdown trade shares of intermediate goods and final goods in all the endogenous countries, which is finally used to reorganize the globally linked input-output table.

\section{Appendix 5: Estimation of the YNU-GIO Tables}

Our estimation process of annual YNU-GIO tables follows flowchart presented in Fig. 6. First of all, we collect NIOTs, ${ }^{22}$ for 29 endogenous countries, valued in corresponding national currencies and rearrange them according to the YNU-GIO industry classification system for benchmark years 2000, 2005 and/or nearest years. In the meantime, we also prepare YNU-GIO classified industry-specific outputs, intermediate goods demand and intermediate goods supply, value-added, exports and imports in annual basis from 1997 to 2012 using UNSD National Accounts Database ${ }^{23}$ and UNIDO INDSTAT Database. Then we apply RAS method ${ }^{24}$ on the benchmark tables along with the

\footnotetext{
22 Basically, we use NIOTs from OECD Input-Output Database for comparability and consistency in industry classification. However, NIOTs not available from the OECD database, we use the tables published by respective national statistical organization in that country.

23 UNSD National Accounts Main Aggregates Database does not cover Taiwan data, so we use the Taiwanese data published by National Statistics, Republic of China (Taiwan).

24 See, for example, Miller and Blair (2009), pp. 313-20 for the details of the RAS method.
} 
industry-specific output and intermediate goods supply and demand data for each of the endogenous countries, which yields 16 annual (1997 to 2012) NIOTs for each 29 endogenous countries valued in respective national currency. Thus estimated NIOTs in national currencies are then converted into the US dollar based NIOTs with respect to annual exchange rates provided by UNSD's National Account Main Aggregates Database. Major advantage of using national currency based NIOTs for the RAS estimation is that the newly estimated NIOTs are less likely to be affected by fluctuation of the bilateral exchange rates.

Secondly, we split intermediate goods and final goods transactions of each NIOTs into domestically procured goods and imported goods. We further separate import blocks of intermediate goods and final goods according to its source country using source country breakdown import shares of intermediate and final goods, respectively. The source country breakdown import shares are calculated from 3121 categories of 4- or 5-digit SITC3 commodity trade data, which are separated into intermediate goods and final goods (combination of 713 categories of consumption goods and 475 categories of capital goods) on the basis of Broad Economic Category (BEC classification), converted into YNU-GIO industry classification system.

Third, we organize domestic transactions and source country breakdown imports of all 29 endogenous countries as a single inter-country transaction matrix, in such a way that the domestic transaction lies on the diagonal block and corresponding source and destination countries lies on the off-diagonal block for both intermediate goods and final goods transactions. By re-organizing inter-country transaction blocks for intermediate goods and final goods transactions, value-added blocks, and output blocks, we get the unbalanced version of globally linked input-output table. In other words, at country level, sum of intermediate inputs (both domestic and imported) and value-added in the unbalanced table corresponds to gross input. However, sum of domestic and exported intermediate and final goods does not add up to gross output on the unbalanced table. Such difference occurs due to the use of source country breakdown import share to figure out the source country of imported goods. As we know that disparity in trade data as a reporter and partner is inevitable (i.e., in trade data country A's import of goods from country B is not same as country B's export to country A or vice versa.), we must adjust the unbalanced table to get the balanced one because difference in gross input and gross output contradicts the fundamental law of input-output table, which states that the gross input and gross output must be equal.

\footnotetext{
Abbreviations

BEC: Broad economic categories; GDP: Gross domestic product; GFC: Global financial crisis; GVC: Global value chain; HK: Hong Kong; ICIO: Inter-country input-output; IIO: International input-output; INDSTAT: Industry Statistics Database; ISIC: International Standard Industrial Classification of All Economic Activities; NIOT: National input-output table; OECD: Organisation for Economic Co-operation and Development; OPEC: Organization of the Petroleum Exporting Countries; ROA: Rest of Asia; ROE: Rest of Europe; ROW: Rest of the World; SITC: Standard international trade classification; UN: United Nations; UNIDO: United Nations Industrial Development Organization; US: The United States of America; WIOD: World Input-Output Database; YNUGIO: Global input-output tables estimated at Yokohama National University.
}

Aknowledgements

We are thankful to two anonymous reviewers for their insightful comments and suggestions. 


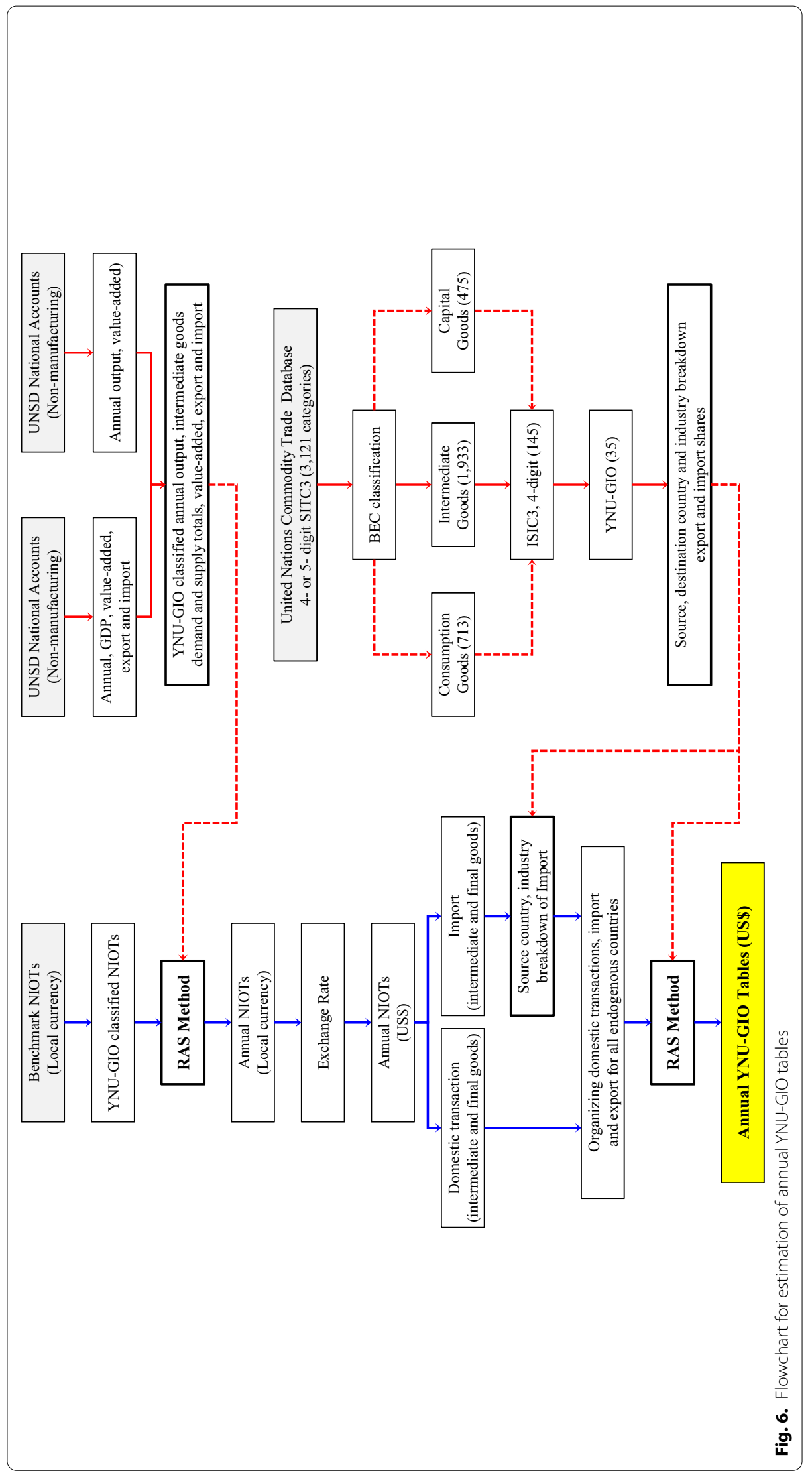




\section{Authors' contributions}

NS constructed YNU-GIO tables, calculated the indices used in the paper, and finalized the paper. KS surveyed the literatures and prepared the original draft. All authors read and approved the final manuscript.

\section{Funding}

This study is financially supported by Yokohama National University and the JSPS (Japan Society for the Promotion of Science) KAKENHI Grant Numbers (16H03638, 17KT0032, 19H01504, 24243041, 24330101, and 26590032).

\section{Availability of data and materials}

Available on request.

\section{Declarations}

Ethics approval and consent to participate

Not applicable.

\section{Consent for publication}

Not applicable.

\section{Competing interests}

Not applicable.

\section{Author details}

${ }^{1}$ Department of Economics, Yokohama National University, 79-3 Tokiwadai, Hodogaya-ku, Yokohama 240-8501, Japan.

${ }^{2}$ Department of Economics, Yokohama National University, Yokohama, Japan.

Received: 4 August 2021 Revised: 26 November 2021 Accepted: 26 November 2021

Published online: 17 December 2021

\section{References}

Ando M, Kimura F (2012) How did the Japanese Exports Respond to Two Crises in the International Production Networks? The Global Financial Crisis and the Great East Japan Earthquake. As Econ J 26(3):261-287

Athukorala P-C (2009) The rise of china and east asian export performance: is the crowding-out fear warranted? The World Econ 32(2):234-266

Crowley, Meredith A. and Xi Luo, 2011 “ "Understanding the Great Trade Collapse of 2008-09 and the Subsequent Trade Recovery," Economic Perspectives, 2nd Quarter, Federal Reserve Bank of Chicago, pp.44-70.

Daudin G, Rifflart C, Schweisguth D (2011) Who produces for whom in the world economy? Can J Econ 44(4):1409-1538

Ferrarini B (2013) Vertical trade maps. Asian Econ J 27(2):105-123

Foster N, Stehrer R (2013) Value added content of trade: a comprehensive approach. Econ Lett 120:354-357

Hummels D, Ishii J, Yi K-M (2001) The nature and growth of vertical specialization in world trade. J Int Econ 54(1):75-96

Johnson RC, Noguera G (2012) Accounting for intermediates: production sharing and trade in value added. J Int Econ 86:224-236

Kimura F, Obashi A (2011) Production networks in East Asia: what we know so far. ADBI Working Paper Series, No. 320, November

Koopman R, Wang Z, Wei SJ (2008) How much Chinese exports is really made in China - Assessing foreign and domestic value-added in gross exports. NBER Working Paper No.14109

Koopman R, Wang Z, Wei S-J (2012) Estimating domestic content in exports when processing trade is pervasive. J Dev Econ 99(1):178-189

Koopman R, Wang Z, Wei S-J (2014) Tracing value-added and double counting in gross exports. Am Econ Rev 104(2):459-494 Miller RE, Blair PD (2009) Input-Output Analysis: Foundations and Extensions, 2nd edn. Cambridge University Press, Cambridge

Nagengast AJ, Stehrer R (2014) Collateral imbalances in intra-European trade? Accounting for the differences between gross and value added trade balances. European Central Bank Working Paper No. 1695

Ng ECY (2010) Production fragmentation and business-cycle comovement. J Int Econ 82(1):1-14

Shimizu J, Sato K (2015) Abenomics, yen depreciation, trade deficit and export competitiveness. RIETI Discussion Paper Series $15-\mathrm{E}-020$

Stehrer R, Foster N, de Vries G (2012) "Value Added and Factors in Trade: A Comprehensive Approach," wiiw (the Vienna Institute for International Economic Studies) Working Paper No. 80

Timmer MP, Erumban AA, Los B, Stehrer R, de Vries GJ (2014) Slicing up global value chains. J Econ Perspect 28(2):99-118

Wang Z, Wei SJ, Zhu K (2013) "Quantifying International Production Sharing at the Bilateral and Sector Level," NBER Working Paper No.19677

\section{Publisher's Note}

Springer Nature remains neutral with regard to jurisdictional claims in published maps and institutional affiliations. 